\title{
An Assessment of the Bacteriological Quality of Commercial Sachet Packaged Water Brands in Awka, Anambra State, Nigeria
}

\author{
Onuorah Samuel*, Odibo Frederick, Orji Michael \\ Department of Applied Microbiology and Brewing, Nnamdi Azikiwe University, P.M.B. 5025 Awka, Nigeria
}

Copyright $\subset 2017$ by authors, all rights reserved. Authors agree that this article remains permanently open access under the terms of the Creative Commons Attribution License 4.0 International License

\begin{abstract}
Some Sachet water brands sold in Awka, Nigeria were assessed bacteriologically to confirm their compliance with the World Health Organization standard for drinking water. The temperature, $\mathrm{pH}$, total bacterial count, total coliform count, faecal coliform count, faecal Enterococci count and Clostridium perfringens count were determined using standard techniques. The temperature values were $27-29^{\circ} \mathrm{C}$; $\mathrm{pH}, 6.2-7.0$; total bacterial count, $35-50 \mathrm{cfu} / \mathrm{ml}$; total colifom count, 4-20MPN/100ml; faecal coliform count, 0-10MPN/100ml; faecal Enterococci count, 0-5MPN/100ml while Clostridium perfringens were absent in all the brands assessed. The bacterial isolates were Escherichia coli (9.7\%), Staphylococcus aureus (18.0\%), Enterobacter aerogenes (17.5\%), Bacillus cereus (14.6\%), pseudomonas aeruginosa $(20.1 \%)$, Proteus mirabilis $(12.1 \%)$ and Enterococcus faecalis (8.0\%). Escherichia coli, Staphylococcus aureus, Enterobacter aerogenes, Bacillus cereus, Pseudomonas aeruginosa, Proteus mirabilis and Enterococcus faecalis were isolated from $66.67 \%, 46.67 \%$, $40.00 \%, 33.33 \%, 53.33 \%, 26.67 \%$ and $20.00 \%$ respectively of the brands. The coliforms $(27.2 \%)$ were the predominant of all the bacterial isolates in the samples. Most of the brands assessed were of poor bacteriological quality and are therefore unfit for drinking without adequate treatment. Routine monitoring of sachet water production and handling by regulatory bodies is commended to handling by regulatory bodies is recommended to safeguard the health of the consuming public.
\end{abstract}

Keywords Assessment, Bacteriological, Quality, Commercial, Sachet and Water

\section{Introduction}

Air, water and food are the three basic necessities of life. Ohumans can survive for about a month without food, a week without water and less than five minutes without air [1]. Water can exist as liquid, gas and solid. It occupies about $70 \%$ of the earth's surface and is an essential commodity needed for the survival of humans, animals, plants and microorganisms. However, good and safe drinking water is unavailable and over 1.1 billion persons (one sixth of the world's population) lack access to clean water [2].

The growing population of most developing countries occur in urban areas thus making it possible to increase the water supply infrastructure as well as improve water supplies [3]. Water is also a most important medium of illness and infant mortality in many developing countries and even in technologically more advanced countries [4]. Although water -related diseases have been largely eliminated in the developed countries, they remain a major concern in most of the developing nations. The high prevalence of diarrhoea among children and infants can be traced to the use of unsafe water and unhygienic practices [5].

Drinking water regulations require that potable water for human consumption must be free from disease-causing bacteria and specific indicator bacteria that are indicative of the presence of these pathogens. Microorganisms that are concerned with water-borne disease include Salmonella $s p$, Shigella sp, Escherichia coli, Vibrio cholerae, [6], Entamoeba histolytica, Giardia lamblia, Balantidium coli, Cryptococcus parvum and Enteroviruses of various clinical at ailments which include Poliovirus, Rotavirus and Hepatitis $E$ virus.

A reliable supply of safe water is often beyond the reach most people in the developing countries. Many of these people in the rural and urban communities depend on sachet water as their drinking water. Sachet packaged water is cheap, popular, easily available and sold in restaurants, and other public places in Nigeria [7]. The sachets are electrically heated and sealed at both ends. There are many different brands of sachet drinking water which are beautifully packages, I properly labeled and advertised in Nigeria [8]. These products are however not free of 
microbial contaminants [9-11].

Awka, the Capital City of Anambra State of Nigeria has a high demand for potable water. The public water supplies are not enough to serve the teaming population. This situation has led to the proliferation of private water supplies in the form of boreholes and wells and the sale of the water emanating from them to the public. Some of these water are packaged in 50-60 cl sachets in questionable hygiene environments and sold to the consumers without regards to their safety. A knowledge of the bacteriological quality of these sachet packaged water is therefore imperative thus in this work, the bacteriological quality of some commercial sachet packaged water in Awka, Nigeria was assessed. It is hoped that the result of the work will further educate the consumers of such water on their bacteriological quality and the dangers the consumption of bacterially-polluted sachet packaged water poses to them.

\section{Material and Methods}

\subsection{Samples Collection}

Fifteen different commercial sachet packaged water brands in Awka, Nigeria were purchased from their retail outlets and labeled A-O. The temperature and $\mathrm{pH}$ of the samples were measured at the point of purchase in the morning. They were thereafter transported to the microbiology laboratory of Nnamdi Azikiwe University Awka in an ice box and analyzed bacteriologically within twenty-four hours of collection. The assessment of the bacteriological quality was carried out from July 6 - July 20 , 2016.

\subsection{Bacteriological Analyses}

\subsubsection{Presumptive Coliform Test}

The most probable number (MPN) technique [12] was used. Ten millilitres $(10 \mathrm{ml})$ of each of the water samples were introduced into each of a first set of five tubes each containing $10 \mathrm{ml}$ double strength bile salt-lactose broth. One millilitre $(1 \mathrm{ml})$ of each of the samples was also introduced into each of a second set of five test tubes each containing $5 \mathrm{ml}$ single strength bile salt-lactose broth. 0.1 millilitre of each of the samples was also introduced into each of a third set of test tubes each containing $5 \mathrm{ml}$ single strength bile salt-lactose broth. Durham tubes were inserted into each of the test tubes. All the test tubes were incubated at $37^{\circ} \mathrm{C}$ for 48 hours and examined for the presence of acid and gas. Acid production was indicated by a change of colour of the broth to yellow while gas production was indicated by the presence of sufficient gas space at the top of the Durham tubes. The potable number of coliforms per $100 \mathrm{ml}$ of each water sample was obtained using the McCrady's Probability Table.

\subsubsection{Confirmatory E. Coli Test}

This test was ed on the fact that only typical $E$. coli will produce gas and indole in Brilliant Green Bile lactose broth at $44^{0} \mathrm{C}$. A loopful of culture from each positive tube from the presumptive test was inoculated into each of two tubes, one containing tryptone water and the other Brilliant Green Bile lactose broth durham tubes were also introduced into the tubes. The tubes were incubated at $44^{0} \mathrm{C}$ for 24 hours after which they were examined for gas and indole production. A few drops of kovac's reagent were added to the brilliant green bile lactose broth after incubation at $44^{0} \mathrm{C}$ for 24 hours. A deep red colouration at the non-aqueous layer indicated indole production. The presence of E. coli was further confirmed by plating out a loopful of culture from the positive presumptive test tubes on eosin methylene blue agar. The plates were incubated at $37^{\circ} \mathrm{C}$ for 24 hours. Colonies of E. coli exhibited a green metallic sheen.

\subsubsection{Completed Coliform Test}

Isolated colonies from the eosin methylene blue agar plates were inoculated into test tubes of lactose broth containing durham tubes and were also streaked on nutrient agar slants. Incubation was carried out at $37^{\circ} \mathrm{C}$ for 24 hours. The presence of gas in the lactose broth as well as the presence of gram negative, non-sporing bacilli on the agar slants indicated the presence of coliform bacteria in the water samples.

\subsubsection{Faecal Enterococci Count}

This was done using the most probable number technique [13]. Ten millilitres $(10 \mathrm{ml})$ of each of the water samples were inoculated into each of first set of five tubes each containing $10 \mathrm{ml}$ of double strength azide dextrose broth. One millilitre $(1 \mathrm{ml})$ of each of the water samples was added to each of a second set of five tubes containing $5.0 \mathrm{ml}$ of single strength azide dextrose broth. $0.1 \mathrm{ml}$ of each of the water samples was also added to each of another set of five test tubes each containing $5 \mathrm{ml}$ of single strength azide dextrose broth. The test tubes were incubated at $35^{\circ} \mathrm{C}$ for 48 hours and examined for growth which was indicated by the turbidity of the broth. The number of tubes that showed turbidity were noted and the most probable number of the faecal Enterococci per $100 \mathrm{ml}$ of each sample was determined using the McCrady's Probability Table. The organism was confirmed by transferring a loopful from the tubes that showed turbidity to plates of bile esculin azide agar and incubating at $35^{\circ} \mathrm{C}$ for 24 hours. The plates were observed for the development of blackish brown colonies with brown halos.

\subsubsection{Clostridium Perfringens Count}

This was also carried out using the most probable number technique [14]. $10 \mathrm{ml}$ of each of the water samples were inoculated into a set of five test tubes each containing $10 \mathrm{ml}$ of differential reinforced double strength clostridial medium. $1 \mathrm{ml}$ of each of the samples was also inoculated into a second 
set of five test tubes each containing $5.0 \mathrm{ml}$ of single strength differential reinforced clostridial medium while $0.1 \mathrm{ml}$ of each of the samples was inoculated into a third set of five tests tubes each containing $5 \mathrm{ml}$ of single strength differential reinforced clostridial medium. Incubation of the tubes was carried out at $37^{\circ} \mathrm{C}$ for 48 hours after which the tubes were observed for the change of colour to black which is a positive reaction.

\subsubsection{Total Bacterial Count}

One millilitre of each of the water samples was introduced into a petri-dish containing ketoconazole at a concentration of $0.05 \mathrm{mg} / \mathrm{ml}$ to inhibit fungal growth. Sterile nutrient agar (NA) was added to the petri-dish and the mixture was gently swirled and left to solidify. Duplicate plates from each sample were prepared and one incubated at $37^{\circ} \mathrm{C}$ for 24 hours and the other incubated at $22^{\circ} \mathrm{C}$ for 24 hours after which the colonies that developed were counted using a colony counter. Only plates that showed between 30 and 300 colonies were counted and the values expressed as colony forming unit per millilitre of the sample. Each colony was purified by repeated sub-culturing on sterile nutrient agar plates and later stored on sterile NA slants for characterization and identification.

\subsubsection{Measurement of Temperature}

The temperature of the water samples was measured by using a thermometer which was inserted into a beaker containing each of the samples. The temperature values were taken when the reading stabilized.

\subsubsection{Measurement of $\mathrm{pH}$}

This was carried out by using a pH meter (JENWAY) that was standardized with $\mathrm{pH}$ buffers 4.0 and 7.0. The electrode of the $\mathrm{pH}$ meter was inserted into each of the samples and the $\mathrm{pH}$ values were taken when the meter reading stabilized.

\subsubsection{Characterization and Identification of the Bacterial Isolates}

The isolates were characterized morphologically and biochemically using standard methods and identified according to the scheme of Cheesbrough [15]. The tests carried out were gram staining, catalase test, coagulase test, oxidase test, motility test, spore test, methyl red test, voges proskaeur test, indole test, citrate utilization test and sugar (glucose, sucrose and lactose) fermentation test.

\section{Results}

The bacterial count of the sachet packaged water samples are shown in Table 1. The total bacterial count ranged from $35 \mathrm{cfu} / \mathrm{ml}$ to $50 \mathrm{cfu} / \mathrm{ml}$. Sample $H$ had the highest count of $50 \mathrm{cfu} / \mathrm{ml}$ while Sample A had the lowest count of $35 \mathrm{cfu} / \mathrm{ml}$. The total coliform count was from 4MPN/100ml to $20 \mathrm{MPN} / 100 \mathrm{ml}$ with Sample M having the highest count of 20MPN/100ml and Sample D having the lowest count of $4 \mathrm{MPN} / 100 \mathrm{ml}$. The faecal coliform count was between $0 \mathrm{MPN} / 100 \mathrm{ml}$ and 10MPN/100ml. Sample K had the highest count of $10 \mathrm{MPN} / 100 \mathrm{ml}$ while Sample A had the lowest count of $0 \mathrm{MPN} / 100 \mathrm{ml}$. Faecal coliforms were not detected in samples B, D, G, I, and O. Faecal Enterococci counts (MPN/100ml) ranged between 0 and 5. In addition, Clostridium perfringens were not detected in any of the samples assessed.

Table 1. Bacterial Count of the Sachet Packaged Water Samples

\begin{tabular}{|c|c|c|c|c|c|}
\hline Sample & $\begin{array}{l}\text { Total bacterial } \\
\text { count }(\mathrm{cfu} / \mathrm{ml})\end{array}$ & $\begin{array}{c}\text { Total coliform count } \\
\text { (MPN/100ml) }\end{array}$ & $\begin{array}{c}\text { Faecal coliform count } \\
(\mathrm{MPN} / 100 \mathrm{ml})\end{array}$ & $\begin{array}{l}\text { Faecal Enterococci } \\
\text { count (MPN/100ml) }\end{array}$ & $\begin{array}{c}\text { Clostridium perfringens } \\
\text { count (MPN/100ml) }\end{array}$ \\
\hline A & 35 & 6 & 2 & ND & ND \\
\hline B & 41 & 10 & ND & ND & ND \\
\hline $\mathrm{C}$ & 40 & 9 & 5 & ND & ND \\
\hline $\mathrm{D}$ & 37 & 4 & ND & ND & ND \\
\hline E & 42 & 8 & 4 & ND & ND \\
\hline $\mathrm{F}$ & 45 & 13 & 9 & 5 & ND \\
\hline G & 43 & 7 & ND & ND & ND \\
\hline $\mathrm{H}$ & 50 & 14 & 8 & ND & ND \\
\hline I & 38 & 5 & ND & ND & ND \\
\hline $\mathrm{J}$ & 39 & 11 & 6 & ND & ND \\
\hline $\mathrm{K}$ & 37 & 15 & 10 & 4 & ND \\
\hline $\mathrm{L}$ & 42 & 11 & 7 & 2 & ND \\
\hline M & 44 & 20 & 9 & ND & ND \\
\hline $\mathrm{N}$ & 40 & 17 & 8 & ND & ND \\
\hline $\mathrm{O}$ & 49 & 12 & ND & ND & ND \\
\hline $\begin{array}{c}\text { WHO } \\
\text { Standard }\end{array}$ & 100 & 10 & 0 & 0 & 0 \\
\hline
\end{tabular}


Table 2. Morphological and Biochemical Characteristics Of The Bacterial Isolates From The Sachet Packaged Water Samples

\begin{tabular}{|c|c|c|c|c|c|c|c|c|c|c|c|c|c|c|c|}
\hline Isolate & form & $\begin{array}{l}\text { Gram } \\
\text { Staining }\end{array}$ & $\begin{array}{l}\text { Motility } \\
\text { test }\end{array}$ & $\begin{array}{l}\text { Catalase } \\
\text { test }\end{array}$ & $\begin{array}{c}\text { Indole } \\
\text { test }\end{array}$ & $\begin{array}{l}\text { Methyl } \\
\text { red test }\end{array}$ & $\begin{array}{c}\text { Voges } \\
\text { proskaeur } \\
\text { test }\end{array}$ & $\begin{array}{c}\text { Coagulase } \\
\text { test }\end{array}$ & $\begin{array}{l}\text { Oxidase } \\
\text { test }\end{array}$ & $\begin{array}{l}\text { Spor } \\
\text { e test }\end{array}$ & $\begin{array}{c}\text { Citrate } \\
\text { Utilization } \\
\text { test } \\
\end{array}$ & $\begin{array}{c}\text { Glucose } \\
\text { fermentation } \\
\text { test }\end{array}$ & $\begin{array}{c}\text { Sucrose } \\
\text { fermentation } \\
\text { test }\end{array}$ & $\begin{array}{c}\text { Lactose } \\
\text { fermentation } \\
\text { test }\end{array}$ & Identity \\
\hline 1 & Rod & - & + & + & + & + & - & - & - & - & - & + & - & + & Escherichia coli \\
\hline 2 & Coccus & + & + & - & + & - & - & + & - & - & - & + & + & + & $\begin{array}{c}\text { Staphylococcus } \\
\text { aureus }\end{array}$ \\
\hline 3 & Rod & - & - & - & - & - & - & - & - & - & + & + & + & - & $\begin{array}{c}\text { Enterobacter } \\
\text { aerogenes }\end{array}$ \\
\hline 4 & Rod & + & + & - & - & - & - & - & - & + & - & + & + & - & Bacillus cereus \\
\hline 5 & Rod & - & + & - & - & - & - & - & + & - & + & - & - & - & $\begin{array}{c}\text { Pseudomonas } \\
\text { aeruginosa }\end{array}$ \\
\hline 6 & Rod & - & + & + & + & + & - & - & - & - & + & + & + & + & $\begin{array}{c}\text { Proteus } \\
\text { mirabilis }\end{array}$ \\
\hline 7 & Coccus & - & - & - & - & - & + & - & - & - & + & + & + & + & $\begin{array}{c}\text { Enterococcus } \\
\text { faecalis }\end{array}$ \\
\hline
\end{tabular}

$+=$ Positive reaction

$=$ Negative reaction 
The morphological and biochemical characteristics of the bacterial isolates from the sachet packaged water samples are presented in Table 2. They were identified as Escherichia coli, Staphylococcus aureus, Enterobacter aerogenes, Bacillus cereus, Pseudomonas aeruginosa, Proteus mirabilis, and Enterococcus faecalis.

The occurrence of the bacteria in the sachet packaged water samples is presented in Table 3. Ten of the samples (66.67\%) had Escherichia coli while only three $(20.00 \%)$ had Enterococcus faecalis in them. The coliforms had the highest occurrence of $27.2 \%$ while Enterococcus faecalis had the lowest occurrence of $8.0 \%$ in the sachet packaged water samples assessed. All the samples also had coliforms in them.

Table 3. Occurrence of the Bacteria in the Sachet Packaged Water Samples

\begin{tabular}{|c|c|c|}
\hline Bacteria & $\begin{array}{c}\text { Number of } \\
\text { samples with the } \\
\text { isolates (\%) }\end{array}$ & $\begin{array}{c}\text { Number of } \\
\text { Isolates (\%) }\end{array}$ \\
\hline Escherichia coli & $10(66.67)$ & $60(9.7)$ \\
\hline Staphylococcus aureus & $7(46.67)$ & $112(18.0)$ \\
\hline Enterobacter aerogenes & $6(40.00)$ & $109(17.5)$ \\
\hline Bacillus cereus & $5(33.33)$ & $91(14.6)$ \\
\hline Pseudomonas aeruginosa & $8(53.33)$ & $125(20.1)$ \\
\hline Proteus mirabilis & $4(26.67)$ & $75(12.1)$ \\
\hline Enterococcus faecalis & $3(20.00)$ & $50(8.0)$ \\
\hline
\end{tabular}

The temperature and $\mathrm{pH}$ values of the sachet packaged water samples are presented in Table 4 . The temperature ranged between $27^{\circ} \mathrm{C}$ and $29^{\circ} \mathrm{C}$. Samples $\mathrm{C}, \mathrm{G}, \mathrm{K}$ and $\mathrm{O}$ each had the highest temperature of $29^{\circ} \mathrm{C}$ while Samples A, D, and $\mathrm{H}$ each had the lowest temperature of $27^{\circ} \mathrm{C}$. The $\mathrm{pH}$ of the water samples were from 6.2 to 7.0. Sample L had the highest $\mathrm{pH}$ of 7.0 while Sample K had the lowest $\mathrm{pH}$ of 6.2.

Table 4. Temperature and $\mathrm{pH}$ Values of the Sachet Packaged Water Samples

\begin{tabular}{|c|c|c|}
\hline Sample & Temperature $\left.\mathbf{~}^{\mathbf{}} \mathbf{C}\right)$ & $\mathbf{p H}$ \\
\hline A & 27 & 6.5 \\
\hline B & 28 & 6.9 \\
\hline C & 29 & 6.8 \\
\hline D & 27 & 6.8 \\
\hline E & 28 & 6.7 \\
\hline F & 28 & 6.6 \\
\hline G & 29 & 6.5 \\
\hline H & 27 & 6.7 \\
\hline I & 28 & 6.6 \\
\hline J & 28 & 6.8 \\
\hline K & 29 & 6.2 \\
\hline L & 28 & 7.0 \\
\hline M & 28 & 6.7 \\
\hline N & 28 & 6.3 \\
\hline O & 29 & 6.5 \\
\hline WHO Standard & $\mathbf{2 5 - 4 0}{ }^{\mathbf{C}}$ & $\mathbf{6 . 5 - 8 . 5}$ \\
\hline
\end{tabular}

\section{Discussion}

Total bacterial count represents the total bacterial load in the water samples. It also reflects the general hygiene condition of the samples. The result of this study showed the presence of bacteria in all the samples examined (Table 1). However they complied with the WHO standard of less than 100 heterotrophic bacteria per $100 \mathrm{ml}$ of water. This result agreed with the studies carried out by Adekunle et al; [16], Ezeugwunne et al; [10] and Oladipo et al; [11] which showed the presence of bacteria in the sachet water samples they examined in Ibadan, Nnewi and Ogbomosho respectively, all in Nigeria.

The presence of bacteria in the samples assessed may be attributed to the poor quality of the water sources, improper sterilization of the packaging materials, poor hygienic condition of the producing and packaging environments, contamination from the air, soil, filling and sealing machines, packaging tables, packaging personnel, improper handling during loading and distribution to consumers as well as the time between production and use by the public.

Coliform bacteria are organisms that are present in the environment and in the faeces of all warm-blooded animals and humans and are gram negative, facultative anaerobes and non-sporing rods that may be motile or not and ferment lactose with the production of acid and or gas when incubated at $37^{\circ} \mathrm{C}$ [17]. Their presence in drinking water indicates that disease-causing organisms could be in the water system. Total coliforms are indicators of drinking water quality and are commonly found in the soil and vegetation. They include Escherichia coli, Klebsiella species, Citrobacter species and Enterobacter species [18].

Forty percent of the samples met the WHO permissible limit of 10 coliforms per $100 \mathrm{ml}$ of water (Table 1). Olaoye and Onilude [19] assessed the microbiological quality of sachet-packaged drinking water in Western Nigeria and its public health significance and detected total coliforms in some of them. Kassenga [20] also detected total coliforms in $4.6 \%$ of the plastic-bagged drinking water he examined in Dares Salaam, Tanzania. Obiri-Danso et al; [9] also detected total coliforms in $4.5 \%$ of the factory-bagged sachet water they examined in Kumasi, Ghana.

Faecal coliforms are a group within the total coliform family which are found in great quantities in the intestines and faeces of humans and animals [17]. They are considered more accurate indicators of faecal contamination of animal or human wastes than the total coliforms. Their presence in drinking water often indicates recent faecal contamination showing that there is a greater risk that pathogens are present than if only total coliforms are detected. $33.33 \%$ of the sachet packaged water samples assessed met the WHO standard of zero faecal coliforms per $100 \mathrm{ml}$ of water sample.

Addo et al [21] studied the bacteriological quality of the sachet water produced and sold in Teshie-Nungua Suburbs of Accra, Ghana and detected faecal coliforms in them. Obiri-Danso et al; [9] carried out the microbiological evaluation of sachet water in Ghana and reported that $2.3 \%$ 
of the factory-bagged sachet water contained faecal coliforms. Olaoye and Onilude [19] however detected faecal coliforms in $2.2 \%$ of the sachet -packaged water samples they examined in Western Nigeria while Edema et al [7] isolated Escherichia coli from $87 \%$ of the samples they examined in Nigeria.

Faecal Enterococci can be found within stomachs and intestines of humans and animals. They are also applied as indicators of water pollution. The presence of faecal Enterococci indicates the presence of faecal pathogens in water. Faecal Enterococci were detected in $20.0 \%$ of the water samples assessed. However, Olaoye and Onilude [19] detected faecal Enterococci in 5\% of the factory-bagged sachet water samples they assessed in Western Nigeria. The high incidence of coliforms and faecal Enterococci in the samples examined may be attributed to the contamination of the water sources by human and or animal excreta.

Clostridium perfringens were not isolated from any of the water samples examined. This indicated that the pollution of the samples was as a result of faecal contamination of some recent times.

Escherichia coli, Staphylococcus aureus, Enterobacter aerogenes, Bacillus cereus, Pseudomonas aeruginosa, Proteus mirabilis and Enterococcus faecalis were isolated from the samples assessed (Table 2). The gram negative rods were the predominant bacteria isolated. Olaoye and Onilude [19] isolated Escherichia coli, Pseudomonas aeruginosa, Enterobacter aerogenes, Proteus mirabilis and Staphylococcus aureus in the water samples they examined in Western Nigeria. Obiri-Danso et al; [9] isolated Escherichia coli, Enterobacter aerogenes and Enterococcus spp from the water samples sold on the streets of Kumasi, Ghana while Edema et al; [7] isolated Escherichia coli and Enterococcus faecalis from the sachet packaged water they examined in Nigeria.

Escherichia coli occurred in $66.67 \%$, Staphylococcus aureus in $46.67 \%$, Enterobacter aerogenes in $40.00 \%$, Bacillus cereus in $33.33 \%$, Pseudomonas aeruginosa in $53.33 \%$, Proteus vulgaris in $26.67 \%$ while Enterococcus faecalis was detected in $20.00 \%$ of the water samples assessed (Table 3). The majority of the samples examined contained total coliforms. Escherichia coli (9.7\%), Staphylococcus aureus (18.0\%), Enterobacter aerogenes (17.5\%), Bacillus cereus (14.6\%), Pseudomonas aeruginosa $(20.1 \%)$, Proteus mirabilis $(12.1 \%)$ and Enterococcus faecalis $(8.0 \%)$ were isolated from the samples (Table 3 ). The result showed that the total coliforms (27.2\%) were the dominant bacteria in the samples indicating that many of the sachet packaged water samples were contaminated with faeces. Escherichia coli were isolated from majority of the samples assessed in low numbers. This may be attributed to the variation in the response of organisms to different sterilization methods.

The temperatures of the water samples assessed were within the mesophilic range (Table 4) and were probably suitable for the growth of the bacteria in the water samples.
The temperature values were within the World Health Organization permissible limit $\left(25-40^{\circ} \mathrm{C}\right)$. The temperature of any water body affects the rate of proliferation of microorganisms. The $\mathrm{pH}$ values of most of the samples (Table 4) were within the permissible limit of 6.5-8.5 established by regulatory bodies [22]. The lower the $\mathrm{pH}$ values the more acidic the water while the higher the $\mathrm{pH}$ values the more alkaline the water becomes. Low $\mathrm{pH}$ may induce the corrosion of metals and pipe works and their leaching into the water thereby leading to serious health problems when their concentrations exceed the permissible limit.

The bacterial isolated in this study have been known to cause diseases of humans. Escherichia coli is an intestinal flora and is the best indicator of faecal pollution of water [21]. Its presence indicates faecal contamination of the water which may be of human or animal origin. The presence of Escherichia coli also indicates the possible presence of pathogenic bacteria, viruses and protozoans [23]. The bacterium has been linked to diarrhoeal diseases, urethrocystitis, prostatis and pyelonephritis. Enterobacter aerogenes are gram-negative bacteria and opportunistic pathogens that are ubiquitous in nature. Their presence in the intestinal tracts of animals results in their wide distribution in soil, water, sewage, plants and humans. The bacteria cause a variety of conditions including eye and skin infections, meningitis, pneumonia, bacteremia and urinary tract infections [24].

Enterococcus faecalis is a bacterium that is found in human faeces and in the intestines of many-warm blooded animals. It is a leading cause of nosocomial infections and is also responsible for urinary tract infections, bacteremia, endocarditis, meningitis and can be found in wound infections along with many other bacteria [25]. Proteus mirabilis is a gram-negative, rod-shaped bacterium that can be found as a free living microbe in soil and water. It is also normally found in the gastrointestinal tracts of human and causes urinary tract infections. It can also lead to the production of kidney and bladder stones [26].

Staphylococcus aureus is a gram-positive coccus and is frequently found in the nose, respiratory tract and on the skin [27]. It can cause a range of illnesses such as pimples, impetigo, boils, cellulitis, carbuncles, abcesses, pneumonia, meningitis, endocarditis, bacteremia, sepsis and osteomyelitis [28]. The presence of this bacterium in some of the water samples is an indication of contamination arising from humans and their activities.

Bacillus cereus is an opportunistic human pathogen that produces toxins and is commonly found in the soil and gastrointestinal tract of ruminants and humans. The toxins can cause severe nausea, vomiting and diarrhoea. Immunocompromised patients are susceptible to bacteremia, endocarditis, septic meningitis, pneumonia, gangrene, cellulitis, infant death, lung abcesses and endophthalmitis [29]. The presence of the bacterium in the water samples may be because of the easy dissemination of their spores which can withstand adverse environmental conditions. 
Pseudomonas aeruginosa is a gram negative, rod-shaped, monoflagellated bacterium that has been found in environments such as the soil, water, humans, animals, plants, sewage and hospitals. It is an opportunistic human pathogen that often colonizes immunocompromised patients such as those with cystic fibrosis, cancer and AIDS and may cause life-threatening infections in humans, including nosocomial pneumonia, urinary tract infections, sepsis, folliculitis, malignant otitis externa and skin infections in patients who have suffered burns [30].

In view of the health risk the consumers of bacterially-polluted sachet packaged water are exposed to, it is imperative that adequate hygienic conditions must be maintained before, during and after production of the sachet water to reduce the ingestion of these organisms which may adversely affect human health.

\section{Conclusions}

This study showed that most of the sachet packaged water samples assessed did not comply with the World Health Organization Standard for drinking water with regards to the coliforms and faecal Enterococci and therefore unsafe for human consumption. Routine monitoring of the sachet water producing factories, the producing environment, water source, packaging materials and production machines by regulatory agencies as well as the observance of good manufacturing practices and regular bacteriological analysis of the samples are recommended.

\section{REFERENCES}

[1] R. Sooryamoorthy, P. Anthony. Managing water and water users: Experiences from Kerala, University Press of America. P 28, 2003.

[2] J.M. Hughes, J.P. Koplan. Saving lives through global safe water. Journal of Emerging Infectious Diseases. Vol. 11, No.10, 1636-1637, 2005. DOI:10.3201/eid1110.051099.

[3] A. Gadgil. Drinking water in developing countries. Annual Review of Energy and the Environment. Vol. 23, 253-286, 1998. DOI:10.1146/annurev.energy.23.1.253.

[4] T.E. Ford. Microbiological safety of drinking water: United States and Global Perspectives. Environmental Health Perspectives. Vol. 107, 191-206, 1999.http://ehpnet1.niehs.n ih.gov/docs/1999/suppl-1/191-206ford/abstract.html.

[5] I.I. Mile, J.A. Jande, B.I. Dagba. Bacteriological contamination of well water in Makurdi Town, Benue State, Nigeria. Pakistan Journal of Biological Sciences, Vol. 15, 1048-1051, 2012. DOI:10.3923/Pjbs.2012.1048.1051.

[6] M.E. Birmingham, L.A. Lee, N. Ndayimirije, S. Nkurikiye, B.S. Hersh, G.J. Wells, M.S. Deming. Epidemic cholera in Burundi: Patterns of transmission in the Great Rift Valley Lake Region. Lancet. Vol. 349, No. 9057, 981-985, 1997. DOI: $10.1016 / \mathrm{S} 0140-6736$ (96)08478-4.
[7] M.O. Edema, A.O. Atayese, M.O. Bankole. Pure water syndrome: Bacteriological quality of sachet-packaged drinking water sold in Nigeria. African Journal of Food, Agriculture, Nutrition and Development. Vol. 11, No.1, 4595-4609, 2011. DOI: 10.4314/ajfand.v.IIiI.65885.

[8] C.A. Ekwunife, S.O. Okafor, C.N. Ukaga, N.A. Ozumba, C.I. Eneanya, Parasites associated with sachet drinking water (pure water) in Awka, South-Eastern Nigeria. Sierra Leone Journal of Biomedical Research. Vol. 2, No. 1, 23-27, 2010. http://dx.doi.org/10.4314/SIjbr.v2iI.56592.

[9] K. Obiri-Danso, A. Okore-Hanson, K. Jones. The microbiological quality of drinking water sold on the streets in Kumasi, Ghana. Letters in Applied Microbiology. Vol. 37, No.4, 334-339, 2003. DOI:10.1046/j.1472-765x.2003.01403 .X.

[10] I.P. Ezeugwunne, N.R. Agbakoba, N.K. Nnamah, I.C. Anahalu. The prevalence of bacteria in packaged sachets water sold in Nnewi, South East Nigeria. World Journal of Dairy and Food Sciences. Vol. 4, No.1, 19-21, 2009. https://www.researchgate.net/publication/242422542.

[11] I.C. Oladipo, I.C. Onyenike, A.O. Adebiyi. Microbiological analysis of some vended sachet water in Ogbomosho, Nigeria. African Journal of Food Science. Vol. 3, No. 12, 406-412, 2009. http://www.acadjourna.org/ajfs.

[12] J.L. Oblinger, J.A. Koburger. Understanding and teaching the most probable number technique. Journal of Milk and Food Technology. Vol. 38, No. 9, 540-545, 1975.

[13] S. Abbott, B. Caughley, G. Scott. Evaluation of Enterolert for the enumeration of Enterococci in the marine environment. New Zealand Journal of Marine and Freshwater Research. Vol. 32, No. 4, 505-513, 1998. http://dx.doi.org/10.1080/002 88330.1998 .9516839 .

[14] C. Abeyta, M.M. Wekell, C.A. Kaysner, R.F. Stott, E.V. Raghubeer, J.R. Matches, J.T. Peeler. Media evaluation and behavior of Clostridium perfringens as an adjunct indicator of quality in shellfish growing areas. Water Science and Technology. Vol. 20, No. 6-7, 63-70, 1988. Wst.iwaponline. com/content/20/6-7/63.

[15] M. Cheesbrough. Laboratory manuals. District laboratory practice in tropical countries. University Press, United Kingdom, Pp 145-157, 2006.

[16] L.V. Adekunle, M.K.C. Sridhar, A.A. Ajayi, P.A. Oluwade, J.F. Olawuyi. An assessment of the health and socio-economic implications of sachet water in Ibadan, Nigeria: a public health challenge. African Journal of Biomedical Research. Vol. 7, No. 1, 5-8, 2004.http//www.re searchgate.net/publication/27800827.

[17] S.C. Edberg, E.W. Rice, R.J. Karlin, M.J. Allen. Escherichia coli: the best biological drinking water indicator for public health protection. Journal of Applied Microbiology. Vol. 88, No. 51, 106S-116S, 2000. DOI:10.1111/j.1365-2672.2000.tb 05338.x.

[18] K. Chao, C. Chao, W. Chao. Evaluation of colilert-18 for detection of coliforms and Escherichia coli in subtropical freshwater. Applied and Environmental Microbiology. Vol. 70, No.2, 1242-1244, 2004. doi:10.1128/AEM.70.2.1242-12 44.2004 .

[19] O.A. Olaoye, A.A. Onilude. Assessment of microbiological quality of sachet-packaged drinking water in Western Nigeria 
and its public health significance. Public Health. Vol. 123, No.11, 729-734, 2009. doi:10.1016/j. puhe.2009.09.015.

[20] G.R. Kassenga. The health-related microbiological quality of bottled drinking water sold in Dar es Salaam, Tanzania. Journal of Water and Health. Vol. 5, No. 1, 179-185, 2007. DOI:10.2166/wh.2006.052.

[21] K.K. Addo, G.I. Mensah, M. Bekoe, C. Bonsu, M.L. Akyeh. Bacteriological quality of sachet water produced and solid in Teshie- Nungu suburbs of Accra, Ghana. African Journal of Food, Agriculture, Nutrition and Development. Vol. 9, No.4, 1-12, 2009. http://dx.doi.org/10.4314/ajfand.v9i4.43874.

[22] World Health Organization. Guidelines for drinking water quality, $3^{\text {rd }}$ edition, Recommendations. WHO Press, Geneva, Switzerland, P 398, 2006.

[23] E. Kara, H.G. Ozdilek, E.E. Kara. An investigation on physical, chemical and bacteriological quality of municipal supplies and well waters of the towns and city centre in the province of Nigde, Turkey. International Journal of Environmental Health Research. Vol. 14, No.2, 151-156, 2004. www.ncbi.nlm.nih.gov/pubmed/15203460.

[24] W.E. Sanders Jr, C.C. Sanders. Enterobacter spp: pathogens poised to flourish at the turn of the century. Clinical Microbiology Reviews. Vol. 10, No.2, 220-241, 1997. http://cmr.asm.org.

[25] B.E. Murray. The life and times of the Enterococcus. Clinical
Microbiology Reviews. Vol. 3, No.1, 46-65, 1990. DOI: 10.10.1128/CMR.3.1.46.

[26] C. Coker, C.A. Poore, L. Xin, H.L.T. Mobley. Pathogenesis of Proteus mirabilis urinary tract infection. Microbes and infection. Vol. 2, No. 12, 1497-1505, 2000. www. Intechopen.com.

[27] A.M. Cole, S. Tahk, A. Oren, D. Yoshioka, Y.A. Kin, A. Park, T. Ganz. Determinants of Staphylococcus aureus nasal carriage. Clinical Diagnostic Laboratory Immunology. Vol.8, No.6, 1064-1069, 2001. doi:10.1128/CDLI.8.6.1064-1069.2 001 .

[28] J. Kluytmans, A. van Belkum, H. Verbrugh. Nasal carriage of Staphylococcus aureus: epidemiology, underlying mechanisms and associated risks. Clinical Microbiology Reviews. Vol. 10, No.3, 505-520, 1997. http://cmr.asm.org.

[29] L. Wijnands, J. B. Dufrenne, M. Zwietering, F. M. van Leusden. Spores from mesophilic Bacillus cereus strains germinate better and grow faster in simulated intestinal fluid than spores from psychrotrophic strains. International Journal of Food Microbiology. Vol. 112, No.2, 120-128, 2006. DOI:10.1016/jfoodmicro.2006.06.015.

[30] K. Botzenhardt, G. Doring. Ecology and epidemiology of Pseudomonas aeruginosa. Pseudomonas aeruginosa as an opportunistic pathogen. Pp 1-18, 1993. DOI: 10.1007/978-1-4615-3036-7 1. 